\title{
UJI AKTIVITAS ANTIOKSIDAN PADA ASTEROIDEA (Linckia laevigata) DARI PERAIRAN TONGKAINA KECAMATAN BUNAKEN KOTA MANADO
}

\author{
Kristoper A. Lidongi ${ }^{1}$, Chatrien. A. L. Sinjal ${ }^{2}$, Kurniati Kemer ${ }^{2}$, Remy E.P Mangindaan ${ }^{2}$, \\ Grevo S. Gerung ${ }^{2}$, Sammy Longdong ${ }^{3}$
}

1. Mahasiswa Program Studi IImu Kelautan, FPIK, UNSRAT Manado

2. Staf Pengajar Program Studi IImu Kelautan, FPIK, UNSRAT Manado

3. Staf Pengajar Program Studi Budidaya Perairan, FPIK, UNSRAT Manado

Penulis korespondensi : Kristoper A. Lidongi ; kristoperanugrah1998@gmail.com

\begin{abstract}
ABSTRAK
Indonesia memiliki sumber daya hayati yang begitu melimpah sehingga menghasilkan banyak potensi senyawa-senyawa bioaktif yang berguna untuk bahan farmasi dan bahan lainnya, dimana salah satunya ialah antioksidan. Antioksidan merupakan zat yang dapat mencegah atau memperlambat kerusakan sel yang diakibatkan oleh radikal bebas. Penelitian ini bertujuan untuk menganalisis seberapa kuat kandungan aktivitas antioksidan yang ada didalam tubuh asteroidea ( Linckia laevigata) yang diambil diperairan Tongkaina Kecamatan Bunaken Kota Manado. Dari penelitian ini didapatkan bahwa nilai inhibisi pada ekstrak etanol Linckia laevigata memiliki aktivitas antioksidan yang cukup kuat dimana ekstrak tersebut mengalami peningkatan dari konsentrasi $10 \mathrm{mg} / \mathrm{L}$ dengan nilai rata-rata $67,3 \%$, konsentrasi $15 \mathrm{mg} / \mathrm{L}$ sebesar $67,8 \%$, konsentrasi $20 \mathrm{mg} / \mathrm{L}$ sebesar 68,8 dan konsentrasi yang paling besar ialah $25 \mathrm{mg} / \mathrm{L}$ mendapatkan nilai rata-rata sebesar 69\%. Peningkatan persen penghambatan dari ekstrak etanol Linckia laevigata, menunjukkan bahwa konsentrasi ekstrak berkontribusi besar terhadap kemampuan ekstrak untuk mengurangi radikal bebas. Dalam penelitian ini, uji DPPH dilakukan dengan mengamati penurunan absorbansi pada panjang gelombang $517 \mathrm{~nm}$ menggunakan spektrofotometer UV-Vis, dimana penurunan nilai absorbansi sebagai akibat dari penurunan intensitas warna. Sedangkan vitamin $\mathrm{C}$ sebagai pembanding memiliki hasil yang lebih besar dari ekstrak sampel Linckia laevigata yang membuktikan bahwa kandungan antioksidan dari sampel tersebut memiliki hasil yang cukup stabil.
\end{abstract}

Kata kunci : Senyawa bioaktif, Linckia laevigata, Antioksidan, Vitamin C

\begin{abstract}
Indonesia has abundant biological resources that produce many potential bioactive compounds that are useful for pharmaceuticals and other materials, one of which is antioxidants. Antioxidants are substances that can prevent or slow down cell damage caused by free radicals. This study aims to analyze how strong the antioxidant activity is in the body of asteroidea (Linckia laevigata) taken in Tongkaina waters, Bunaken District, Manado City. And this study found that the inhibition value of the ethanolic extract of Linckia laevigata had strong antioxidant activity where the extract increased and the concentration was $10 \mathrm{mg} / \mathrm{L}$ with an average value of $67,3 \%$, a concentration of $15 \mathrm{mg} / \mathrm{L} \mathrm{of} 67,8 \%$, a concentration of $20 \mathrm{mg} / \mathrm{L}$ of $68,8 \%$ and the highest concentration of $25 \mathrm{mg} / \mathrm{L}$ getting an average value of $69 \%$. The increace in the percentage of inhibition and the ethanolic extract of Linckia laevigata, showed that the concentration of the extract contributed greatly to the ability of the extract to reduce free radicals. In this study, the DPPH test was carried out by observing the decrease in absorbance wavelength of $517 \mathrm{~nm}$ using UV-Vis spectrophotometer,where the decrease in absorbance value as a result and a decrease in color intensity. While vitamin $C$ as a comparison has a greater yield and sample extract of Linckia laevigata which proves that the antioxidant content and the sample has a fairly stable result.
\end{abstract}

Keywords: Bioaktif compounds, Linckia laevigata, Antioxidant, Vitamin C 


\section{PENDAHULUAN}

Asteroidea merupakan salah satu organisme laut yang masuk dalam filum Echinodermata yang memiliki struktur tubuh berbentuk seperti bintang (berlengan 5). Jumlah Bintang laut yang ada di dunia diperkirakan terdapat 1800 jenis, dimana di perairan Indonesia diperkirakan ada 400 species atau sebesar $22 \%$ dari jumlah total species bintang laut yang ada di dunia (Ernawati $d k k$, 2019). bintang laut ditemukan mempunyai lima lengan, kadang juga terlihat hanya empat bahkan enam lengan, jika salah salah satu lengan maka lengan baru akan terbentuk segera karena adanya daya regenerasi hewan ini yang cukup tinggi (Fitriana, 2010).

Bintang laut memiliki komponen bioaktif yang terdiri dari alkaloid, steroid, flavonoid, saponin, yang memiliki aktivitas antioksidan, antibakteri, antifungi (Runtuwene $d k k, 2017)$.Salah satu species bintang laut yang menghasilkan aktivitas antioksidan ialah species linckia laevigata. Linckia laevigata sendiri sering ditemukan di daerah tropis (Fitriana, 2010). Tujuan dari penelitian ini ialah untuk menganalisis seberapa kuat aktivitas antioksidan yang terkandung dalam tubuh asteroidea (Linckia laevigata) yang diambil dari perairan Tongkaina Kecamatan Bunaken Kota Manado

Antioksidan merupakan senyawa yang dapat menetralkan atau meredam radikal bebas, serta menghambat terjadinya kerusakan sel (Suryaningrum dkk, 2006). Antioksidan bekerja dengan cara mendonorkan satu elektronnya kepada senyawa yang bersifat oksidan sehimgga aktivitas senyawa oksidan tersebut bisa terhambat, dimana antioksidan menstabilkan radikal bebas dengan melengkapi kekurangan elektron yang dimiliki radikal bebas dan menghambat terjadinya reaksi berantai dari pembentukan radikal bebas.

Metode penangkapan radikal bebas DPPH merupakan metode yang paling banyak digunakan dalam pengujian aktivitas antioksidan, karena metode ini hanya sederhana dimana hanya menggunakan sedikit sampel dan yang paling penting ialah metode ini memiliki akurasi yang paling tinggi dari metode lainnya sebesar $70 \%$.

\section{METODE PENELITIAN}

\section{Waktu dan Lokasi Penelitian}

Penelitian ini dilakukan pada bulan Juni sampai agustus 2021. Lokasi penelitian dilakukan pada 2 lokasi berbeda : (1) Untuk proses penanganan awal hingga proses ekstraksi dilakukan di Laboratorium Biologi Molekuler dan Farmasetika Laut, Fakultas Perikanan dan IImu Kelautan, (2). Untuk pengujian aktivitas antioksidan dilakukan di Laboratorium Farmakognosi dan Fitokimia, Fakultas Matematika dan IImu Pengetahuan Alam, Universitas Sam Ratulangi, Manado.

\section{Pengambilan dan preparasi sampel}

Sampel asteroidea (linckia laevigata) diambil dari perairan Tongkaina, Kota Manado dengan menyusuri pesisir pantai pada saat terjadinya surut terendah. Sampel yang didapatkan langsung dimasukkan kedalam cool box untuk dibawah ke laboratorium, setelah itu sampel dibersihkan dengan air mengalir, setelah itu dipotong kecil-kecil, setelah dipotong kecilkecil sampel langsung dimasukkan ke dalam botol dengan menggunakan pelarut alkohol $95 \%$ yang kemudian diberikan label.

\section{Ekstraksi dengan Metode Maserasi}

Ekstraksi dilakukan dengan memakai metode maserasi dengan menggunakan pelarut etanol $95 \%$. Sampel yang telah dipotong kecil-kecil ditimbang sebesar 150 gram yang kemudian dimasukkan kedalam gelas beker yang telah diisi pelarut etanol. Setelah itu sampel dibiarkan terendam dalam larutan penyari selama $2 \times 24$ jam pada temperatur kamar yang dilindungi dari cahaya dan sesekali dikocok. 
Hasil ekstraksi kemudian disaring menggunakan kertas saring $16 \times 16 \mathrm{~cm}$ kemudian diambil filtratnya dan residu dibuang. Filtrat dari proses ekstraksi $2 x$ pengulangan dicampurkan. Filtrat diuapkan dengan menggunakan evaporator $40^{\circ} \mathrm{C}$ sampai tidak ada lagi pelarut yang tersisa, yang kemudian dimasukkan kedalam falcon tube $50 \mathrm{~mL}$ menggunakan mikropipet 1000 $\mu \mathrm{L}$, sehingga diperoleh ekstrak kasar etanol dari asteroidea Linckia laevigata yang kemudian ekstrak kasar tersebut dibawah ke Laboratorium Farmakognosi dan Fitokimia, Fakultas Matematika dan Ilmu Pengetahuan Alam, Universitas Sam Ratulangi, Manado.

\section{Pembuatan Larutan Ekstrak Linckia laevigata}

Sebanyak $100 \mathrm{mg}$ ekstrak etanol asteroidea linckia laevigata, dilarutkan dalam alkohol 95\% $100 \mathrm{~mL}$ (konsentrasi 1000 ppm). Dengan masing-masing konsentrasi $25 \mathrm{mg} / \mathrm{L}, 20 \mathrm{mg} / \mathrm{L}, 15 \mathrm{mg} / \mathrm{L}$, dan $10 \mathrm{mg} / \mathrm{L}$ dihitung dengan menggunakan rumus pengenceran, yaitu :

$$
M_{1} \bullet V_{1}=M_{2} \bullet V_{2}
$$

Pada keempat konsentrasi, masingmasing hasil yang didaptkan dari hasil $\mathrm{V}_{1}$ dipipet dan ditambahkan alcohol 95\% hingga mencapai tanda batas ( $10 \mathrm{~mL})$, kemudian dipindahkan kedalam tabung reaksi dan ditutup menggunakan aluminium foil untuk digunakan pada perlakuan selanjutnya. (Sinjal $d k k, 2019$ ).

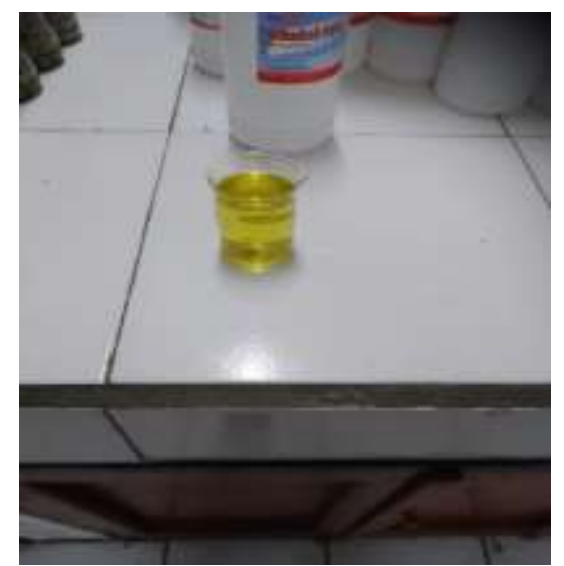

Gambar 1. Larutan ekstrak Linckia laevigata (dokumentasi pribadi

\section{Pembuatan Larutan DPPH}

Sebanyak $4 \mathrm{mg}$ serbuk DPPH ditimbang dan dilarutkan dalam etanol 95\% sebanyak $100 \mathrm{~mL}$. selanjutnya larutan stok DPPH dilakukan pengujian kontrol, di uji pada spektrofotometer UV-Vis dengan panjang gelombang antara $400-800 \mathrm{~nm}$.

\section{Pengujian Aktivitas Antioksidan dengan Metode DPPH}

Penentuan aktivitas penangkal radikal bebas DPPH ( Burda dan Olezek, 2001) dilakukan dengan mengambil sebanyak $2 \mathrm{~mL}$ ekstrak alkohol asteroidea Linckia laevigata, dengan kosentrasi 25 $\mathrm{mg} / \mathrm{L}, 20 \mathrm{mg} / \mathrm{L}, 15 \mathrm{mg} / \mathrm{L}$ dan $10 \mathrm{mg} / \mathrm{L}$ yang akan ditambahkan masing-masih 1,5 mL larutan DPPH dalam alkohol dan divorteks selama 2 menit. Berubahnya warna ungu menjadi warna kuning menunjukan efisiensi penangkal radikal bebas. Diukur absorbansi pada spektofotometer UV-Vis dengan panjang gelombang $517 \mathrm{~nm}$ setelah diinkubasi selama 30 menit. Kemudian diamati perbandingan dengan vitamin $\mathrm{C}$ p.a sebagai standar. Setelah absorbansi didapat, aktivitas penangkapan radikal bebas (persen inhibisi) dihitung sebagai persentase berkurangnya warna DPPH dengan menggunakan rumus berikut: (Sinjal $d k k, 2019)$. 
$\%$ inhibisi $=1-\frac{\text { Absorbansi sampel }}{\text { Absorbansi kontrol }} \times 100 \%$

\section{HASIL DAN PEMBAHASAN}

Organisme Sampel

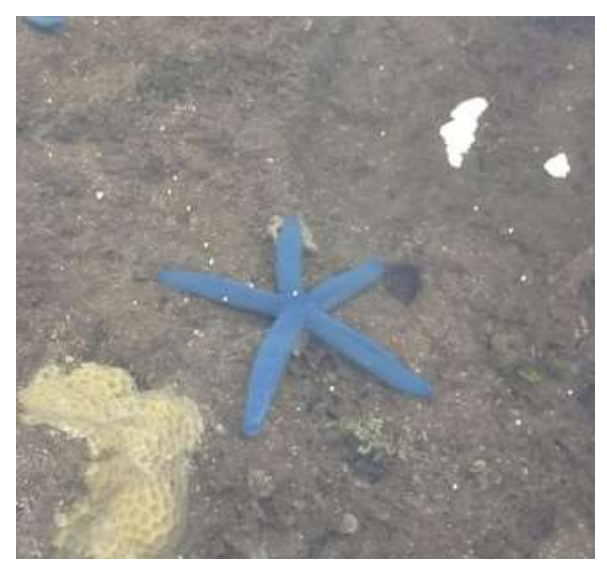

Gambar 2. Linckia laevigata (dokumentasi pribadi)

\section{Hasil Ekstrak Kasar}

Tabel 1. Hasil Pengujian Aktivitas Antioksidan

\begin{tabular}{|c|c|c|c|c|c|}
\hline Sampel & $\begin{array}{c}\text { Konsentrasi } \\
\mathrm{mg} / \mathrm{L}\end{array}$ & $\begin{array}{c}\text { Pengulangan } \\
1\end{array}$ & $\begin{array}{c}\text { Pengulangan } \\
2\end{array}$ & $\begin{array}{c}\text { Pengulangan } \\
3\end{array}$ & Rata-rata \\
\hline \multirow{3}{*}{ Ekstrak } & 10 & $68,1 \%$ & $62,2 \%$ & $71,8 \%$ & $67,3 \%$ \\
Etanol & 15 & $70 \%$ & $66,9 \%$ & $66,5 \%$ & $67,8 \%$ \\
& 20 & $67,2 \%$ & $69,5 \%$ & $69,7 \%$ & $68,8 \%$ \\
& 25 & $66,8 \%$ & $69,5 \%$ & $70,7 \%$ & $69 \%$ \\
& & & & & \\
Vitamin & 10 & $95,3 \%$ & $95,2 \%$ & $95 \%$ & $95,1 \%$ \\
C & 15 & $95,2 \%$ & $95,3 \%$ & $95,2 \%$ & $95,2 \%$ \\
& 20 & $95,2 \%$ & $95,5 \%$ & $95,6 \%$ & $95,4 \%$ \\
& 25 & $95,3 \%$ & $95,6 \%$ & $95,6 \%$ & $95,5 \%$ \\
& & & & & \\
\end{tabular}

Sampel Linckia laevigata dengan berat $150 \mathrm{gr}$, diekstraksi dengan metode maserasi dan didapatkan ekstrak kasar bintang laut biru (Linckia laevigata) dengan berat sebesar 63,71 gr.

\section{Pengujian Aktivitas Antioksidan}

Dari penelitian yang dilakukan didapatkan bahwa nilai inhibisi pada ekstrak etanol Linckia laevigata memiliki aktivitas antioksidan yang cukup kuat dimana ekstrak tersebut mengalami peningkatan dari konsentrasi $10 \mathrm{mg} / \mathrm{L}$ dengan nilai rata-rata $67,3 \%$, konsentrasi $15 \mathrm{mg} / \mathrm{L}$ sebesar 67,8 $\%$, konsentrasi $20 \mathrm{mg} / \mathrm{L}$ sebesar 68,8 dan konsentrasi yang paling besar ialah $25 \mathrm{mg} / \mathrm{L}$ mendapatkan nilai rata-rata sebesar $69 \%$. Hasil penelitian menunjukkan bahwa kandungan antioksidan pada Linckia laevigata mengalami peningkatan seiring dengan semakin bertambahnya konsentrasi ekstrak etanol sampel tersebut, dimana bisa dilihat pada tabel 1 
etanol Linckia laevigata memiliki aktivitas antioksidan yang cukup kuat dimana ekstrak tersebut mengalami peningkatan dari konsentrasi $10 \mathrm{mg} / \mathrm{L}$ dengan nilai rata-rata $67,3 \%$, konsentrasi 15 $\mathrm{mg} / \mathrm{L}$ sebesar $67,8 \%$, konsentrasi $20 \mathrm{mg} / \mathrm{L}$ sebesar 68,8 dan konsentrasi yang paling besar ialah $25 \mathrm{mg} / \mathrm{L}$ mendapatkan nilai ratarata sebesar $69 \%$. Hasil penelitian menunjukkan bahwa kandungan antioksidan pada Linckia laevigata mengalami peningkatan seiring dengan semakin bertambahnya konsentrasi ekstrak etanol sampel tersebut, namun peningkatan tertinggi tidak melewati kandungan antioksidan sebesar $75 \%$.

Ekstrak etanol dari Linckia laevigata dengan konsentrasi $25 \mathrm{mg} / \mathrm{L}$ memiliki persentase penghambatan rata-rata tertinggi yaitu sebesar $69 \%$. Peningkatan persen penghambatan dari ekstrak etanol Linckia laevigata, menunjukkan bahwa konsentrasi ekstrak berkontribusi besar terhadap kemampuan ekstrak untuk mengurangi radikal bebas. Dalam penelitian ini, uji DPPH dilakukan dengan mengamati penurunan absorbansi pada panjang gelombang 517 $\mathrm{nm}$ menggunakan spektrofotometer UV-Vis, dimana penurunan nilai absorbansi sebagai akibat dari penurunan intensitas warna. Sedangkan vitamin

C sebagai pembanding memiliki hasil yang lebih besar dari ekstrak sampel Linckia laevigata yang membuktikan bahwa kandungan antioksidan dari sampel tersebut memiliki hasil yang cukup stabil.

\section{KESIMPULAN}

Dari penelitian yang dilakukan didapatkan bahwa aktivitas antioksidan yang didapatkan pada ekstrak etanol Linckia laevigata tergolong cukup kuat, dimana ekstrak tersebut mengalami peningkatan dari konsentrasi $10 \mathrm{mg} / \mathrm{L}$ dengan nilai ratarata $67,3 \%$, konsentrasi $15 \mathrm{mg} / \mathrm{L}$ sebesar
$67,8 \%$, konsentrasi $20 \mathrm{mg} / \mathrm{L}$ sebesar 68,8 dan konsentrasi yang paling besar ialah 25 $\mathrm{mg} / \mathrm{L}$ mendapatkan nilai rata-rat a sebesar $69 \%$, dimana hasil penelitian ini menunjukkan bahwa konsentrasi ekstrak berkontribusi besar terhadap kemampuan ekstrak untuk mengurangi radikal bebas.

\section{SARAN}

1. Perlu adanya penelitian lebih lanjut tentang aktivitas antioksidan Linckia laevigata terlebih khusus dari perairan tongkaina untuk dijadikan produk-produk yang menjadi bahan farmasi dan kosmetika.

2. Perlu adanya penelitian lebih lanjut untuk mengetahui struktur kimia dan kandungan senyawa apa yang terdapat dalam tubuh Linckia laevigata.

3. Perlu adanya perbandingan senyawa bioaktif yang terdapat dari beberapa species bintang laut terutama senyawa antioksidan.

\section{DAFTAR PUSTAKA}

Burda, S. dan W. Oleszek. 2001. Antioxidant and antiradical activities of flavonoids. J. Agric. Food chem. 49: 2774-2779.

Ernawati, N.W., I.W. Arthana. dan N.M. Ernawati. 2019. Kelimpahan keanekaragaman dan pertumbuhan alami bintang laut (asteroidea) diperairan Pantai Semawang dan Pantai Samuh, Bali. Current Trends in Aquatic Science II (1), 46-53.

Fitriana, N. 2010. Inventarisasi bintang laut (echinodermata: asteroidea) di pantai Pulau Pari, Kabupaten ADM. Kepulauan Seribu. Jurnal ilmiah factor exacta. 3 (2).

Pursetyo, K.T., Wahyu T. dan H. Pramono. 2015. Perbandingan morfologi kerang darah diperairan Kenjeran dan perairan Sedati. Jurnal IImiah Perikanan dan Kelautan. 7 (1). 
Runtuwene, R.K., D.S. Wewengkang. dan G. Citraningtyas. 2017. Aktivitas Antibakteri Ekstrak Bintang Laut Linckia laevigata yang diperoleh dari Teluk Manado. Pharmacon Jurnal Ilmiah Farmasi-Unsrat, 6 (4): 2302-2493.

Sinjal, C.A., D.S. Wewengkang dan H.C. Runtuwene. 2019 (Laporan akhir Riset Dasar Unggulan Unsrat).

Suryaningrum, T.D., T. Wikanta. dan H. Kristiana. 2006. Uji aktivitas senyawa antioksidan dari rumput laut Halymenia harveyana dan Eucheuma cottonii. Jurnal Pascapanen dan Bioteknologi Kelautan dan Perikanan Vol 1 (1). 